\title{
A Study of Farmers Awareness towards Zero Tillage in Haryana State
}

\author{
Pawan Kumar $^{1 *}$, P.S. Shehrawat ${ }^{1}$, Pushpa ${ }^{2}$ and J.S. Malik ${ }^{1}$ \\ ${ }^{1}$ Department of Extension Education, ${ }^{2}$ Department of Mathematics and Statistics, CCS \\ Haryana Agricultural University, Hisar, Haryana, India
}

*Corresponding author

\section{A B S T R A C T}

The study was conducted in two different ecological zones of Haryana to determine the

\section{Keywords}

Awareness, Zero

Tillage,

Conservation

Practice, soil

erosion

Article Info

Accepted:

17 April 2019

Available Online:

10 May 2019 farmers' awareness towards zero tillage to conserve the soil as the degradation is increasing day by day. A group of 240 respondents were interviewed with help of a well designed interview schedule. The responses of farmers were obtained on three-point continuum scale as 'fully aware' 'aware' and 'not aware' against each statement and weight age were given as 3,2 and 1, respectively. Aggregate total weight age score was calculated for each statement and on the basis of so calculated score, total weighted score and weighted mean score were obtained. Finally, rank orders were assigned according to the obtained weighted mean score. Out of the total respondents 51.66 per cent respondents belongs to small and marginal category of land holding, majority $(85.41 \%)$ of respondents had high availability of farm inputs and out of the total respondents 58.33 per cent respondent had at least canal and 54.17 per cent respondents had at least submersible pump as the main source of irrigation. The study elaborates that awareness about 'Zero tillage reduce the field preparatory cost' and 'Zero tillage reduce the labor and fuel costs' were high among the farmers. However, awareness about 'Zero tillage helps to reduce the infestation of weed' and 'Zero tillage helps in carbon Sequestrations' were low.

\section{Introduction}

The concerns on the sustainability of agricultural systems have increased recently because the agricultural edges have already expanded near to the maximum all over the world (Cardoso et al., 2013). In many regions of the world, there is growing concern about the soil productivity and wider environmental implications of conventional agricultural practices, and especially the tilling of soils by plough, disk or hoe. This has prompted governments and farmers to explore alternative production methods that maintain soil structure and productivity. Conservation tillage, be it minimum- or no-till, is an obvious and increasingly popular alternative, but so too is the use of cover crops, extensive crop rotations, and straw mulch. These wellknown practices have recently been packaged and promoted under the label 'conservation agriculture' by the Food and Agriculture 
Organization of the United Nations (FAO), the European Conservation Agriculture Federation (ECAF).

Zero tillage is an extreme form of minimum tillage. It is also known as-no till farming, direct drilling etc. Zero tillage is a way of growing crops or pasture from year to year without disturbing the soil through tillage. Zero tillage is an agricultural technique which increases the amount of water that in filtrates into the soil and increases organic matter retention and cycling of nutrients in the soil. In many agricultural regions it can reduce or eliminate soil erosion. It increases the amount and variety of life in and on the soil, including disease-causing organisms and disease suppression organisms. The most powerful benefit of zero tillage is improvement in soil biological fertility, making soils more resilient. Farm operations are made much more efficient, particularly improved time of sowing and better traffic ability of farm operations.

Tilling of soil is used to remove weeds, shape the soil into rows for crop plants and furrows for irrigation. This leads to unfavorable effects, like soil compaction; loss of organic matter; degradation of soil aggregates; death or disruption of soil microbes and other organisms and soil erosion where top soil is washed or blown away. Soil tillage conventional system based on annual ploughing had the effect of reducing hydro stability of structural aggregates, increasing vulnerability to degradation by soil compaction, erosion etc. (Cerbari, 2011). Zero tillage avoids these effects by excluding the use of tillage.

Continuous zero till needs to be managed very differently in order to keep or increase yield on the field. Adopting zero tillage and other conservation tillage practices can enhance soil quality in cropping systems where synthetic agro-chemicals are relied on for crop nutrition and weed control (Carr et al., 2013).

Evers and Agostini (2001) suggested that no tillage (NT) systems can be potentially beneficial and it need to receive more attention as future for agricultural and rural development. It is also suggested that there is urgency to raise the awareness about scope and understanding of no-till systems for its better adaptation and adoption. Knowler (2003) showed that a great number of soil conserving practices typically produce net financial benefits for adopters, based on a meta-analysis of over one hundred farm-level financial analyses. He found that over $65 \%$ of the analyses revealed net financial benefits from adoption.

The overall goal of conservation agriculture is to make better use of agricultural resources (than does conventional agriculture) through the integrated management of available soil, water and biological resources such that external inputs can be minimized (FAO, 2001; Garc1'a-Torres et al., 2003). Once aware, farmers were more likely to participate, as long as there was a good fit with the farm situation and the costs of compliance were low. Compliance costs are often an obstacle to adoption (Wilson, 2000).

\section{Farmers' awareness towards zero tillage (ZT)}

It is clear from data presented in Table 1 that respondents had high awareness about 'ZT reduce the field preparatory cost' and 'reduce the labour and fuel costs' which were ranked $1^{\text {st }}$ and $2^{\text {nd }}$ position with highest weighted mean scores (WMS) 1.93 and 1.78, followed by 'helps to maintain adequate soil moisture content in soil' was ranked $3^{\text {rd }}$ position with WMS 1.73. Awareness about 'reduce the irrigation requirement' and 'maintains soil structure', both were equally ranked $4^{\text {th }}$ 
position with WMS 1.68, Followed by 'helps cropping frequency/timeliness', 'decrease soil erosion' and 'helps to reduce the infestation of weed' ranked $5^{\text {th }}, 6^{\text {th }}$ and $7^{\text {th }}$ position with
WMS 1.63, 1.60 and 1.55 , respectively. While, Awareness level was low about 'zero tillage helps in sequestrations of soil carbon' ranked $8^{\text {th }}$ position with WMS 1.23.

Table.1 Farmers' awareness towards zero tillage (ZT)

\begin{tabular}{|c|c|c|c|c|c|c|c|}
\hline S. No. & Statements & $\begin{array}{c}\text { Fully } \\
\text { aware } \\
(\%)\end{array}$ & $\begin{array}{c}\text { Aware } \\
(\%)\end{array}$ & $\begin{array}{l}\text { Not } \\
\text { aware } \\
(\%)\end{array}$ & $\begin{array}{c}\text { Total } \\
\text { Weighted } \\
\text { Score }\end{array}$ & $\begin{array}{l}\text { Weighted } \\
\text { Mean } \\
\text { Score }\end{array}$ & $\begin{array}{l}\text { Rank } \\
\text { Order }\end{array}$ \\
\hline 1 & $\begin{array}{l}\text { Zero tillage reduce the field } \\
\text { preparatory cost }\end{array}$ & $\begin{array}{c}66 \\
(27.50 \%)\end{array}$ & $\begin{array}{c}60 \\
(25 \%)\end{array}$ & $\begin{array}{l}144 \\
(60 \%)\end{array}$ & 462 & 1.93 & I \\
\hline 2 & $\begin{array}{l}\text { Zero tillage reduce the } \\
\text { irrigation requirement }\end{array}$ & $\begin{array}{c}44 \\
(18.33 \%)\end{array}$ & $\begin{array}{c}76 \\
(31.67 \%)\end{array}$ & $\begin{array}{c}120 \\
(50 \%)\end{array}$ & 404 & 1.68 & IV \\
\hline 3 & $\begin{array}{l}\text { Zero tillage reduce the labor } \\
\text { and fuel costs }\end{array}$ & $\begin{array}{c}66 \\
(27.50 \%)\end{array}$ & $\begin{array}{c}56 \\
(23.33 \%)\end{array}$ & $\begin{array}{c}118 \\
(49.17 \%)\end{array}$ & 428 & 1.78 & II \\
\hline 4 & $\begin{array}{l}\text { Zero tillage helps to maintain } \\
\text { adequate soil moisture content } \\
\text { in soil }\end{array}$ & $\begin{array}{c}50 \\
(20.83 \%)\end{array}$ & $\begin{array}{c}76 \\
(31.67 \%)\end{array}$ & $\begin{array}{c}114 \\
(47.50 \%)\end{array}$ & 416 & 1.73 & III \\
\hline 5 & $\begin{array}{l}\text { Zero tillage maintains soil } \\
\text { structure }\end{array}$ & $\begin{array}{c}38 \\
(15.83 \%)\end{array}$ & $\begin{array}{c}86 \\
(35.83 \%)\end{array}$ & $\begin{array}{c}116 \\
(48.33 \%)\end{array}$ & 402 & 1.68 & IV \\
\hline 6 & $\begin{array}{l}\text { Zero tillage helps cropping } \\
\text { frequency/timeliness }\end{array}$ & $\begin{array}{c}35 \\
(14.58 \%)\end{array}$ & $\begin{array}{c}82 \\
(34.17 \%)\end{array}$ & $\begin{array}{c}123 \\
(51.25 \%)\end{array}$ & 392 & 1.63 & V \\
\hline 7 & $\begin{array}{l}\text { Zero tillage helps to reduce the } \\
\text { infestation of weed }\end{array}$ & $\begin{array}{c}30 \\
(12.50 \%)\end{array}$ & $\begin{array}{c}72 \\
(30 \%)\end{array}$ & $\begin{array}{c}138 \\
(57.50 \%)\end{array}$ & 372 & 1.55 & VII \\
\hline 8 & $\begin{array}{l}\text { Zero tillage decrease soil } \\
\text { erosion }\end{array}$ & $\begin{array}{c}30 \\
(12.50 \%)\end{array}$ & $\begin{array}{c}85 \\
(35.42 \%)\end{array}$ & $\begin{array}{c}125 \\
(52.08 \%)\end{array}$ & 385 & 1.60 & VI \\
\hline 9 & $\begin{array}{l}\text { Zero tillage helps in carbon } \\
\text { sequestrations }\end{array}$ & $\begin{array}{c}10 \\
(4.17 \%)\end{array}$ & $\begin{array}{c}35 \\
(14.58 \%)\end{array}$ & $\begin{array}{c}195 \\
(81.25 \%)\end{array}$ & 295 & 1.23 & VIII \\
\hline
\end{tabular}

Fig.1 Farmers' awareness towards zero tillage (ZT)

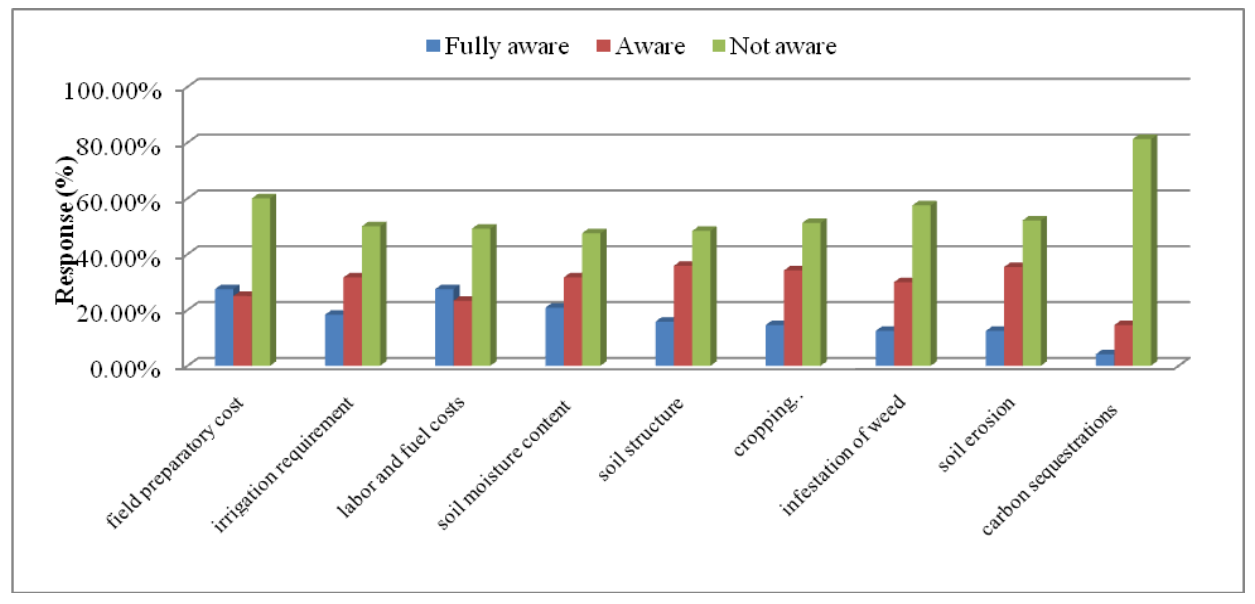


A perusal of data (Fig. 1) indicated that awareness level among respondents regarding reduce the field preparatory cost and reduce the labour and fuel costs was observed to be the highest followed by Zero tillage helps to maintain adequate soil moisture content in soil Moreover, it was observed that awareness level was low among farmers about the helps in sequestrations of soil carbon. Therefore, it is important to raise the awareness level among farmers about the potential of zero tillage in various contexts and more understanding of the zero tillage systems. In context to these findings, Evers and Agostini (2001) reported that there is need to raise awareness of the potential of no tillage.

\section{References}

Carr, P.M., Gramig, G. G. and Liebig, M. A. (2013). Impacts of Organic Zero Tillage Systems on Crops, Weeds, and Soil Quality. Sustainability. 5: 3172320.

Cardoso, EJBN, Vasconcellos RLF, Bini B, Miyauchi MYH, Santos CA, Alves PRL (2003) Soil health: looking for suitable indicators. What should be considered to assess the effects of use and management on soil health. 70: 274-289.

Cerbari, V., (2011). Program de dezvoltareşiimplementare tehnologiilor

conservative înagricultură. Agricultura Moldovei. 5: 7-9.

Evers, G., and Agostini, A. (2001). No-tillage farming for sustainable land management: Lessons from the 2000 Brazil study tour. FAO investment center occasional paper series No. 12: $1-26$

FAO(2001). The economics of soil productivity in Africa. Soils Bulletin, Rome.

Garc1'a-Torres, L., Benites, J., Martı'nezVilela, A., Holgado-Cabrera, A. (2003). Conservation Agriculture: Environment, Farmers Experiences, Innovations, Socio-economy, Policy. Kluwer Academic Publishers, Boston, USA.

Knowler, D.J., (2003). Explaining the financial attractiveness of soil and water conservation - a meta-analysis model. Paper presented at the 2003 Soil and Water Conservation Society's Annual Conference, Spokane, Washington, July 26-30.

Wilson, G., (2000). Financial imperative or conservation concern? EU farmers' motivations for participation in voluntary agri-environmental schemes. Environment and Planning A 32(12), 2161-2185.

\section{How to cite this article:}

Pawan Kumar, P.S. Shehrawat, Pushpa and Malik, J.S. 2019. A Study of Farmers Awareness towards Zero Tillage in Haryana State. Int.J.Curr.Microbiol.App.Sci. 8(05): 2069-2072. doi: https://doi.org/10.20546/ijcmas.2019.805.240 